KÖZÉPESY Szilvia, MÁLNÁSI Tibor, PÁL Vivien, CSÁKÓ Zsófia, VEZMÁR Albert

Nemzeti Népegészségügyi Központ, Budapest

E-mail: kozepesy.szilvia@nnk.gov.hu

DOI: https://doi.org/10.29179/EgTud.2021.3.46

\title{
Gyermekek vizeletében mért jódkoncentráció: trendek és szükséges intézkedések
}

\section{Összefoglalás:}

Mind az elégtelen, mind a túlzott jódellátottságnak is lehet káros egészséghatása a pajzsmirigy múködésére. A vizelet jód koncentrációjának (UIC) mérése nemcsak a jódhiány kimutatása, hanem a túlzott bevitel felderítése miatt is hasznos. Ezen ismeretek birtokában, rendszeres humán biomonitoring (HBM) végzésével az adott populáció mindenkori ellátottsági szintjéhez lehet igazítani a jódpótlás mértékét, így nemcsak a jódhiány okozta betegségteher, hanem a túlzott jódellátottság okozta káros egészséghatások is megelőzhetőek.

Az InAirQ projekt (2016-2019) keretében 9 magyarországi település 23 kiválasztott iskolájában, 9-12 éves gyermekektől ( $N=393)$ vettünk egyszeri vizeletmintát. A vizeletminták jód koncentrációjának meghatározása Sandell-Kolthoff reakción alapuló spektrofotometriás módszerrel történt a Nemzeti Népegészségügyi Központ (NNK) laboratóriumában. A Jász-Nagykun-Szolnok megyei települések iskoláiban a vizelet mintavételekkel egyidőben több ponton levett ivóvízminták jodid koncentrációjának meghatározása szintén a NNK laboratóriumában történt. Az analitikai méréseken kívül kérdőíves felmérést végeztünk, melyben a jód lehetséges forrásaira kérdeztünk rá.

A karcagi és Karcag környéki településeken élő gyermekek vizeletének medián jód koncentrációja 629 ㅆg/l (95\% Cl: 557-667); ez a WHO definíciója szerint túlzott jódellátottságot jelez, ugyanakkor az egyéb településeken élö, vizsgálatba bevont gyermekek esetében a medián UIC 165,5g// (95\% Cl: 148-186) volt, ami megfelelő jódellátottságra utal.

A Karcagon és a környező településeken vett ivóvízmintákban átlagosan 540 g/l jodid koncentrációt mértünk, $580 \mu \mathrm{g} / \mathrm{l}$ mediánnal. A többi település esetében, az NNK 2017. évben végzett országos felmérése alapján 20 ㅆg/l ivóvíz jodid-ion tartalommal számoltunk. Az átlagos vízfogyasztással súlyozott ivóvíz jodid koncentráció és UIC között szignifikáns pozitív az összefüggés ( $R=0,83, p<0,0001)$. Ez alapján és a kérdőívek elemzése alapján valószínúsíthető, hogy a Karcagon és a környező településeken élő gyermekek magas vizeletjód koncentrációját az ivóvíz magas jódtartalma okozza.

Az itt élő gyermekek esetében javasolt csökkenteni az étrendi jódbevitelt, meg kell szüntetni az esetleges jódpótlást, illetve meg kell vizsgálni az ivóvíz jód koncentrációjának csökkentésének a lehetőségét. Az aktuális jódellátottsági helyzet értékelése érdekében továbbra is fontos a rendszeres, egész országra kiterjedő szűrővizsgálatok, illetve HBM vizsgálatok végzése (iskolai szúrések, pajzsmirigy-, vizelet, és vérvizsgálatok, várandósok vizsgálata stb.).

Kulcsszavak: HBM, jódellátottság, jódhiány, túlzott jódellátottság, vizelet jód koncentrációja (IUC) 